A DEPTH INTERVIEW: DEVELOPMENT OF AN: INTEREST IN ART EDUCATION

\title{
Christina Thompson
}

Frank Barron's Artists in the Making is one of many studies concerned with the factors which contribute to the development of the studio artist. There has been little comparable research devoted to the growth of interest in the "other" careers in art. How does one decide to become an art historian, an art critic, or an art educator? Is studio art the usual point of entry to these pursuits? At what time and for what reasons do these more theoretical approaches to art emerge in people's lives?

The questions posed in this interview attempted to trace one individual's path to a career commitment in art education. The subject, Janice Johnson, is now a graduate student in art education. Her undergraduate degree was in painting, and she originally came to The University of Iowa to pursue an advanced degree in art history.

Six major questions were asked of Janice:

(1) How would you describe your present involvement in art?

(2) At this time, what relative emphasis do you place on art and on education? Why?

(3) When did you first become interested in art? What factors or events were influential in creating your interest? In sustaining it?

(4) When did you decide to pursue a career in art? Did you con- 


\section{Christina Thompson}

sider any alternatives?

(5) When did your interest in art education begin? What factors or events were influential in creating it? In sustaining $i t ?$

(6) Do you consider your interest in art education to be mainly concentrated in the area of research or in the area of teaching? Why?

Janice is unable to isolate a single event in her childhood which precipitated her interest in art, although she indicates that the interest must have been apparent quite early in her preschool years. She speculates, "Parents of children who have an interest in art tend to create a myth about them. . . It's a whole myth, a kind of identity, that they've helped to create." She recalls her mother's stories of events she herself cannot remember: her impatience with the ineptitude of adults' drawings and her insistence that "I can do it much better than you can," her choice of an oil painting set from all the wonders of a toystore at the age of three. Janice implies that these incidents have assumed some of their "mythical" quality in retrospect; as her pattern of behavior emerged, these early episodes increasingly were perceived as early warning signs.

A specific public recognition of her ability, the display of one of her watercolors in the local bank, helped to sustain her interest during her elementary school years. She says, "For a week or two I was pretty impossible to be around. . . here I was, exhibiting at age 9!" 


\section{Christina Thompson}

Janice believes that her decision to pursue a career in art was formulated in her junior high and early high school years. This direction was encouraged by an influential teacher, who "wasn't even an art teacher; she taught science and art, but she was a science teacher." She encouraged Janice to elect art courses in high school and college, and Janice recalls, "She thought I had a chance for a career in art. She didn't specify doing what, but I assume she meant teaching."

Janice speaks of her early expectations of a career in art and the changes in perspective which came with maturity. "I wanted to be an artist. I'm sure I didn't really know what that meant, other than the fact that you got to draw and paint and do whatever you did the best you could. I know I didn't know what it meant not to have a secure system of supporting yourself. It was very idealistic. Even through college. . . When I suddenly realized that you can't eat cadmium yellow, I seemed to become more realistic about my life." The only "non-art" alternative Janice has entertained is the teaching of philosophy. However, she considers this a "related," if "more academic approach," to many of the same issues.

Janice's interest in art education was not sudden. She had contemplated this direction while in undergraduate school, but thought that the available program was inadequate. When she returned to graduate school, she became interested in Iowa's art education area and eventually entered the program. Janice feels that art education has facilitated a convergence of her interests, "like ribbons or threads in a warp," now unified in a pattern. 


\section{Christina Thompson}

What factors prompted this change of emphasis? In addition to the realistic assessment of the nutritional properties of paint, Janice explains, "I think my knowledge about art far excels my technical ability, so I'm not satisfied with what I produce. Somehow the ideas behind a work of art seem more exciting to me than the actual work: once I have an idea for something that seems sufficient in itself."

Janice characterizes her present activity in art as mainly theoretical, a "dramatic" but "gradual" shift from her previous studio work. As an lindergraduate, she feels that all her energies were directed at making art. She explains, "Looking at the work of another artist, or reading any type of historical or critical writing was fed into the process of making an art object." She no longer aspires to an identity as "artist," "whereas at one time, that was my major concern."

Art education seems to have replaced painting as an expressive medium in Janice's thought. She speaks of the generative nature of the field: "There's that great appeal that one question seems to lead into another. It hasn't stopped, whereas in my painting the ideas stopped coming, the possibilities stopped coming. The possibilities in art education seem like a fan, spreading out rather than narrowing." Research has evolved as her dominant interest. She has not taught, and admits to "mixed feelings" about her recent student teaching experience. She feels that "researching different aspects of the art process or the teaching proces. . . to make better teachers and better programs for students" is not only a "better focus" for her 


\section{Christina Thompson}

personally, but also promises more effective results for a greater number of children. She concludes, "I think it's important to improve the quality of our educational system in general, and specifically art education." Janice has come to believe that research may be, for her, the most direct route to this goal.

Janice maintains that art has always been "a factor" in her life. In this interview, it is possible to sense the potency of that factor and its centrality to Janice's shifting perspectives from preschool to the present.

It is interesting to contemplate the myth which Janice finds permeating her childhood. Perhaps this is what Nevelson meant in saying, "I did not become anything; I was an artist." The seed of this career was planted early, nurtured by the fables of her childhood, and cultivated by the enthusiasm of her parents and teachers.

The later decisions which led Janice to her present pursuits give evidence of a mature scrutiny of her own strengths and her potential to effect change. A continual process of self-reflection is apparent in these remarks. Although her initial hesitancy about her career as a painter may have been motivated by stark economic realities, she has continued to weigh alternatives in her search for a more personally and professionally satisfying approach to art. She has become, in a sense, a conceptual artist. The attitudes and knowledge which once informed her painting are now realized in another form: the areas of art education which she hopes to research. For Janice, art education seems to be a further direction in her art. 


\section{Christina Thompson}

Issues for further study. I was intrigued by Janice's conception of the "myth" which her parents constructed around "their daughter, the artist." This direction might be followed by investigating the extent to which other artists recognize the creation of such a myth in their own childhoods and the extent to which their subsequent decisions may have been influenced by this parental support. Is this a common phenomenon? Is it a type of self-fulfilling prophecy? Is it as likely to occur with male children as with female?

Another issue, one that has occupied a corner of my thoughts for some time, is the investigation of the ways in which art educators view their work. Are research and teaching considered as adjuncts to studio work, or as expressive acts of the same magnitude as the making of art? How do art educators deal with the dual aspects of their careers, on both philosophical and practical levels?

Methodological note. I find myself increasingly comfortable with the interview methodology; it does require practice to be supportive and yet neutral.

It was somewhat easier to devise questions for an adult subject than it often is for children. There is always the problem of clarity, of phrasing questions so that they are communicative and yet not leading. My second question in this case did not seem to be clear; at any rate, it did not produce the type or content of response which I had intended.

As I transcribe and analyze the data, I always have the desire to immediately schedule a follow-up session. More questions suggest themselves, and it becomes apparent that some very important questions 


\section{Christina Thompson}

were left unasked in the interview. I think that a dialogue could be established in a longitudinal study that would be very profitable, and that would fill in the gaps which present themselves in retrospect. 